\title{
Financial Phantasmagoria: Corporate Image-Work in Times of Crisis
}

\author{
Christian De Cock (Swansea University, c.de-cock@swansea.ac.uk) \\ Max Baker (University of Sydney, m.baker@econ.usyd.edu.au) \\ Christina Volkmann (Swansea University, c.r.volkmann@swansea.ac.uk)
}

\begin{abstract}
Over the period January-December 2008 we collected 241 separate advertisements from 61 financial institutions published in the Financial Times. Reading across the ensemble of ads for themes and evocative images, sketching an outline in symbolic space as it were, provides an impression of the financial imaginaries created by these organizations as the global financial crisis unfolded. In using the term 'phantasmagoria' we move beyond its colloquial sense of a set of strange images designed to dazzle, towards the more technical connotation used by Rancière (2004) who suggested that words and images can offer a trace of an overall determining set-up if they are torn from their obviousness so they become phantasmagoric figures. The latter connotation encourages a search for dissonances, juxtapositions and contradictions in particular imaginaries and is thus close to Jameson's $(1998,2007)$ notion of dialectical criticism. Such an approach is a response to the realization that too much has been ceded too readily to powerful naturalizing forces which have made certain aspects of the recent period of 'capitalism in crisis' very hard to question.
\end{abstract}




\title{
Financial Phantasmagoria: Corporate Image-Work in Times of Crisis
}

\author{
Nothing can be done about crises! \\ Unshakeable above our heads \\ Stands economic law, the not-to-be-known. \\ Terrible is the cyclic recurrence \\ Of natural catastrophes. \\ Brecht (1962: 126), fragment from Saint Joan of the Stockyards
}

\section{Introduction}

Written between 1929 and 1931, Saint Joan of the Stockyards is the product of Bertolt Brecht's (1962) intensive study of the workings of capitalist economies in the late 1920s. His aim in this play was to grasp the real movements of contemporary society and transpose them to the theatre, thus visualising the very real contradictions that striated that society (cf. Jameson, 1998; Schwarz, 2007). Our purpose in this article is to relate the real movements in the economy during 2008 to what we call the 'image-work' of a multitude of financial institutions as they tried to create narratives and images which somehow were meant to distance these organizations from the firestorm that tore through the global economy, whilst expounding the vital role they continued to play in the economy and even in people's daily lives.

Over the period January-December 2008 we collected 241 separate advertisements from 61 financial institutions (banks (164), stock exchanges (23), insurance companies (43) and mutual funds (11) ) which were published in the Financial Times. Almost without exception the 'product' that these ads were trying to sell was the organization itself. Since the readership of the FT consists to a significant extent of people working in, or with an interest in, the financial sector $^{1}$ (Davis, 2005), one function of the ads was clearly to provide some 'cognitive mapping' to a broadly managerial audience. Advertising in the FT can also be seen as a device for mobilizing elite support for particular financial/economic imaginaries (cf. Jessop, 2004) through the release of a barrage of "affective charges" (Thrift, 2008: 243). The way financial institutions framed and assembled narratives and images for public consumption may very well have shaped the popular political imagination about the crisis and should therefore be carefully examined, if not contested (cf. Thompson, 2009).

\footnotetext{
${ }^{1}$ The FT had an average circulation of 432,944 in January 2009, indicating a 3.17\% drop in circulation over the course of 2008. It had a full-rate circulation in the UK of 75,679, with 135,236 copies circulated in the US, 124,358 in Europe and 40,167 in Asia (Busfield, 2009). Davis (2005), on the basis of an extensive series of interviews in the City of London, found that "Everyone reads the Financial Times..." (p.310); as one of his interviewees put it: "reading the $F T$ every morning you make sure you have a relatively broad set of updates ... (p.311)". In a major advertising exercise, the 'we live in financial times' campaign launched in April 2007, the FT had put itself very much at the heart of the new economic imaginary of a financialised economy (cf. De Cock, 2008). The sheer volume of financial ads published in 2008 (241) is remarkable when we compare it to only one year earlier (81 finance ads published in 2007) or the number of new economy ads we collected at the height of the dotcom boom and subsequent crash (133 ads published in 2000).
} 
Perhaps the most striking aspect of the 2008 crisis is how easily the idea was accepted that its happening was unpredictable (cf. Žižek, 2009). Much of the public debate on the causes of the crisis has consequently taken the form of either an 'accidents' theory, explaining the debacle as the result of a variety of contingent actions (incompetent rating agencies, greedy bankers, lazy regulators, or irresponsible consumers), or a 'natural disaster' theory which assumes that basic economic conjunctures wreak periodical devastation like hurricanes or earthquakes do. We start from the somewhat differing proposition that a relatively coherent, if rather metaphysical entity, which has been variously referred to as 'the New Wall Street System' (Gowan, 2009), the 'financialised economy' (Froud et al., 2007), 'financialised capitalism' (Montgomerie and Williams, 2009), or more commonly as 'finance capital' (Glyn, 2006; Jameson, 1997; Lash 2007), should be understood as being deeply implicated in the crisis and therefore in need of exploration.

\section{Representing Finance Capital}

"Present-day capitalism is increasingly financial in its character... Quotidian money is fuelled increasingly by the imaginary that propels global financial markets" (Pryke and du Gay, 2007: 339 - emphasis added).

They key area of concern of this paper is the imaginary of finance capitalism Pryke and du Gay refer to. In exploring the image-work of a large number of financial actors we believe we can start to get a glimpse of how this particular imaginary, in its various dimensions, is given shape. But before we expand upon our way of proceeding and explore our data in more detail, we need to clarify some key concepts, entities and developments in the economic sphere.

We follow Watt and Galgóczi's (2009) designation of 'finance capitalism' as a state “in which the process of financialisation has gone so far that the role of financial motives, markets, actors and institutions can be considered predominant" (p.190). The term financialisation has been used with increasing regularity in recent years to describe the growing and systemic power of finance and financial engineering (Evans and Habbard, 2008; Froud et al., 2007). Whilst the growing role of financial motives, markets and institutions is not an entirely new phenomenon, what is particularly striking is the sheer scale and dominance of the financial sector in $21^{\text {st }}$ century economies (Blackburn, 2006). Panitch and Konings (2009) describe at quite some length the expansion and consolidation of the networks of institutional linkages that sustained and expanded the power of American finance. They suggest that neo-liberalism and financial expansion did not lift the market out of its social context, but rather embedded financial forms and principles more deeply in the fabric of both American society and economy.

Financialisation has thus had a profound impact on the nature and operation of contemporary organizations. No longer can the value of a firm be seen as the sum of the exchange-value of its assets (its fixed and circulating capital) and the variable capital of its labour force. Rather, as Lash (2007:18) puts it, "The exchange-value of a firm is now the sum of a collection of bets on its future profitability... [it] has to do more with capital markets than product markets".

Organizations, and even work teams, are increasingly turning into a bundle of liabilities and assets as the articulation and visibility of surplus throughout the organization is becoming ever more significant. As a result they are always in danger of being broken up and reassembled in 
order to maximize shareholder value (Blackburn, 2008). Even the largest corporations have only a precarious autonomy within an increasingly financialised economy. As Hopwood (2009: 799) suggests: "A whole host of financial concepts, accounting practices and other calculative technologies seemingly have become intimately tied up with what has been the increasingly single minded attention placed not only on profitability itself but also the transference of those profits, particularly to the financial sector".

A simple calculation, based on data from the United States Bureau of Economic Analysis, illustrates the point rather well. From the mid-1930s until the late 1980s profits generated by the financial sector averaged around $20 \%$ of the corporate profits from all other industry sectors combined. Over the last 10 years they averaged closer to $50 \%{ }^{2}$. Of particular note is that the 2008 crisis seems to have been a mere 'blip' for the financial sector as its relative profitability has returned to well above historical trend figures, moving closer again to the pre-crisis $21^{\text {st }}$ century average. This seems to underscore what Froud et al. (2008: 17) referred to as "the mobility and resourcefulness" of finance capital which leaves both critics and champions "wrong footed and struggling to catch up".

- Insert Figure 1 about here -

Once a state such as finance capitalism is 'discovered' (i.e. becomes central in a discourse) it takes on agency. Finance capital - or in its colloquial forms of 'Wall Street' and 'The City' - is then seen to act in the world: it causes events, creates effects (viz. the discussions about 'Wall Street' being the lifeblood of the economy - Žižek, 2009). But finance capitalism is not simply found as an empirical object among other worldly things, and thus has to undergo a process of representational mapping. Any time we try and deal with 'the economy' or 'finance capital' we confront the non-representable (Buck-Morrs, 1995, 2007); we then have to map and explore the imaginaries in order to identify the type of images and allegories that have been invented or mobilized (Jameson 2007). One particular avatar for finance capital would be the image of a stock market ${ }^{3}$, but this is merely one way among others of attempting to personify something that is too complex for representation (Jameson, 1998). Not surprising then, as Amin and Thrift (2004: xxi) suggest, "Work on the image... becomes a prime activity of capitalism".

\section{From Image-Work to Phantasmagoria}

"Today, the most real, mercantile gaze into the heart of things is the advertisement..." (Benjamin, 2002: 476).

\footnotetext{
${ }^{2}$ Our calculations are based on Table 6.16 A-D, Corporate Profits by Industry (www.bea.gov).

${ }^{3}$ A powerful part of this imaginary is the opening bell of the NYSE which features often in news broadcasts that have to relate economic or financial news. The LSE has been reported as wanting to revive "the glamour of the opening bell" as a weapon in a brand war with other stock exchanges: "with electronic trading a common feature across all trading facilities, exchanges need to recreate the rituals associated with a bygone era to help distinguish themselves from upstart rivals" (Grant, 2009).
} 
Giving specific shape to, or creating imaginaries around, a non-representable phenomenon is obviously not a neutral endeavor as Rancière (2007) pointed out. What we are confronted with in our ensemble of ads is "a montage of words and images appropriate for reconfiguring the territory of the visible, the thinkable, and the possible" (Rancière, 2004: 41). The ads, through their work on the image, configure the economic imaginary in such a way that they become a means of sustaining an economy which is dominated by finance, where finance has become the vital 'lifeblood'. For example, one particular powerful imaginary in our sample is predicated on a 'fear and insecurity' scenario to which financial institutions can then offer transcendence or at least a safe haven. The financial crisis is referred to obliquely as 'an increasingly risky world' (ACE), an 'uncertain world' (Zurich), 'market cycles' (Merrill Lynch), 'turbulent/ challenging times' (Deutsche Bank), 'difficult conditions' (BNY Mellon), or 'difficult markets' (HSBC), sometimes accompanied by images of a rough sea (BNY Mellon), waves (Deutsche Bank) and even a ladder with an icy step (HSBC). The crisis thus becomes an 'outside space' which these organizations can position themselves against and help shield us from ('the world changes, our commitment doesn't' - UBS; 'our commitment... unwavering' - Merrill Lynch) or help us 'rise above the risk', as a full page CME ad announced in October 2008 (accompanied by a cartoon image of man atop a mountain poking up through the clouds). Not a single advertisement actually uses the word 'crisis' or refers, heaven forbid, to the massive bail-out.

A key point of our analysis is that we do not focus on advertising agencies (the 'authors') as sources of meaning, but on the systems of convention operating within the discursive system of a social practice (financial advertising in this case). At the heart of our approach lies thus a desire to identify and illuminate the terms in which the ads come to play a function in sustaining and reproducing our faith/trust in financial markets or, to put in it in more prosaic terms, in creating the "Wall Streets of the American Mind" (Morone, 2007: 28). This function has a strong ideological dimension in the Althusserian sense in that the ads offer a representational structure which allows the individual subject (the reader) to conceive or imagine his or her lived relationship to the transpersonal reality of finance capitalism.

What interests us is the network of relationship between the ads and by accounting for these we begin to describe the system of norms that makes them possible (cf. Culler, 1983). This network can be described with Benjamin (2002) as a collective 'dreamworld', or with Barthes (2000) as 'mythology'. For Barthes myths are the forms a society uses to ensure its peace of mind. It is worth quoting him at some length from his seminal 1956 piece Myth Today:

"Myth does not deny things, on the contrary, its function is to talk about them; simply, it purifies them, it makes them innocent, it gives them a natural and eternal justification, it gives them a clarity which is not that of an explanation but that of a statement of fact... it organizes a world which is without contradictions because it is without depth, a world wide open and wallowing in the evident, it establishes a blissful clarity: things appear to mean something by themselves" (Barthes, 2000: 132).

Rancière (2004) suggested that words and images can begin to "offer a trace of the true", of the overall determining set-up, if they are torn from their obviousness in order to become a phantasmagoric figure. He saw this phantasmagoric dimension as having played an essential role in the formation of the critical paradigm of the human and social sciences: "The Marxist theory of fetishism is the most striking testimony to this fact - commodities must be torn out of their 
trivial appearances, made into phantasmagoric objects in order to be interpreted as the expression of society's contradictions" (p.34) [emphasis added]. Similarly for Jameson the dialectic is defined and constituted by the search for and discovery of contradictions, juxtapositions and dissonances. In a recent interview (Jameson, 2007: 194) he outlined three interrelated ways of thinking about the dialectic which serve as our 'method' for analyzing the ads:

1. The emphasis on "the logic of the situation, the constant changeability of the situation, its primacy and the way in which it allows certain things to be possible and others not".

2. The constant undermining or demystifying of various received forms of narrative and historical causality.

3. An emphasis on contradiction: "If at every moment in which we represent something to ourselves in a unified way we try to undo that and see the contradictions and multiplicities behind that particular experience, then we are thinking dialectically".

We proceeded by tearing ads out of the obvious context in which they first appeared and placing them in relation to one another, thus problematizing the meanings readers were supposed to assume. In a sense we are using the ads homeopathically; by working with the images and narratives that the industry itself throws up we hope to make (partially) visible the abstract forces shaping our daily lives. The very activity of analyzing and re-jigging the ensemble of ads proved to be a rather stimulating process, a kind of creative play, "in which the whole reified surface of a period seemingly beyond history and beyond change now submits to a first ludic unbuilding" (Jameson, 1998: 79). Such an approach is a response to the realization that there are "landscapes of space, time and experience that have been ceded too readily to powerful naturalizing forces" (Thrift, 2008: 19) which make certain aspects of the recent crisis very hard to question, or even to think of as problematic in the first place.

The first step in constructing our 'financial phantasmagoria' involved relating general patterns in the ads to the unfolding crisis during 2008. As Jessop (2004) suggested, economic imaginaries must have some significant, albeit necessarily partial, correspondence to real material interdependencies in the actually existing economy and/or in relations between economic and extra-economic activities that needs exploring. To facilitate such an exploration we developed an Excel coding sheet which included the name and type of organization, the month in which the ad was first published ${ }^{4}$, a description of the key image, the strap line, whether the ad contained an (oblique) reference to the crisis, and finally whether the ad made an explicit mention of respectively risk, size and history. This size-history-risk dimension was included after an initial perusal of the raw data suggested this could reveal an interesting 'mythical' aspect. All 241 ads were fully dated and scanned at high resolution so that all authors had at all times full possession of the data set to reflect on.

\footnotetext{
${ }^{4}$ We excluded all 'doubles' (subsequent identical ads). Those with differences in text or image, however small, we included in the sample. In what follows we will date the ads by the month they were published. So (1103) would mean the ad was published on March $11^{\text {th }} 2008$.
} 


\section{Financial Advertising in Times of Crisis}

"[T]he pursuit of a market in almost everything led to a banker's nightmare in which key assets could not be valued" (Blackburn 2008: 67).

“... It may be more productive, then, to combine all the descriptions and to take an inventory of their ambiguities - something that means talking as much about fantasies and anxieties as about the thing itself' (Jameson, 2000: 49).

When situating our sample of ads in the broader economic context of the crisis, it is worth remembering that 2008 was a year that roughly can be divided into three parts. The first four months of the year saw a steadily stabilizing picture from the initial shock that occurred during the summer of 2007 for the majority (but not all) financial institutions. Central banks contributed to this prematurely rosy picture. For example, the bi-annual Bank of England Financial Stability Report suggested in April 2008: "Prices in some credit markets are likely to overstate the losses that will ultimately be felt by the financial system and the economy as a whole... Conditions should improve as market participants recognize that some assets look cheap relative to credit fundamentals." For good measure the Deputy Governor added: "While there remain downside risks, the most likely path is that confidence and risk appetite will return gradually in the coming months."

Events over the next four months belied such optimism as investors became progressively more edgy and assets proved more and more difficult to value. Corporate messages appeared increasingly more out-of-tune with events on the ground over the months of July and August. For example, on July $17^{\text {th }}$ the CEO of Merrill Lynch stated in a call to analysts: "We believe that we are in a very comfortable spot in terms of our capital... We've been, I think, pretty balanced in terms of what we sold... we have not simply liquidated stuff at any price we could get". On July $28^{\text {th }}$ the company announced an $\$ 8.5$ billion share offering and revealed it had sold CDO's valued at $\$ 11 \mathrm{bn}$ in June for $\$ 6.7 \mathrm{bn}$, or at $22 \%$ of their original face- value.

But it was only during the final four months of the year that we could genuinely talk about 'Capitalism in Crisis'. This period saw Lehman wiped out and Merrill Lynch and AIG rescued by the Bank of America and the American government respectively. The October Bank of England Financial Stability Report now declared that "the global banking system has arguably undergone its biggest episode of instability since the start of World War I." The American editor of the Financial Times (Freeland, 2008) put it rather more prosaically: "the US version of the market economy - and many of its leading players - has failed more spectacularly than even the darkest dreams of Noam Chomsky could predict." At the danger of over-generalizing, we could say that a typical financial institution would see a stable share price in the first four months of the year, an average $25 \%$ drop in the next four months, and a dramatic 50\% drop in the final four months. Table 1, outlining the share price movements of a selection of organizations included in our sample (we have included the actual number of ads they published) gives an insight into these trends.

- Insert Table 1 about here - 
If we exclude the holiday month of August, we see that the publishing frequency of the ads increased as uncertainty built, reaching a crescendo in October 2008 in the immediate aftermath of what the JP Morgan Global Outlook Report referred to as "A Bad week in Hell".

- Insert Figure 2 about here -

Size, History, Risk

It is with particular respect to history, size and the notion of risk that the mythical dimension of the image-work comes to the fore as companies tried to situate themselves within the unfolding crisis. This particular type of ad aimed to smooth the crisis and restore peace of mind. As Barthes (2000) suggested, myth aims to provide innocence, "a natural and eternal justification... a clarity which is not that of an explanation but that of a statement of fact" (p.132).

Within our sample 89 ads made reference to company size. This may have been in the form of the total number of employees or countries in which they had operations, stating their market capitalization, or even explicitly stating that they were the " 6 th largest bank in the world" (Santander 0407). Size is also alluded to in a more imaginary sense where the effect on the viewer is one of awe. In relation to the crisis this seems to suggest 'we are bigger than this'. For instance an enormous powerful bull (often taking up more than half of the copy) is used in a series of Merrill Lynch ads (e.g.: 1107, 2107). Other ads display people in a small proportion to (and in a sense dominated by) large architectural forms and cityscapes (e.g.: ACE 0311, Aviva 2010, Credit Suisse 1305, Standard Chartered 1508).

The ads also tend to portray organization age or history as a guarantor of future security. Citi, for example, state in their strap line: "Proud History. Secure Future" (2611 - text only full page ad). Merrill Lynch (1510) affirm: "Markets... have always found a way to come back and grow over the long time...That's history." The associated image here is one of a bull standing on a hill guarding a non-descript city. Within this ad Merrill Lynch draw on a relatively myopic view of history which is centred on the certainty of economic conjunctures, something we shall return to later. Yet, this over-simplified view of the past is taken as an undeniable indicator of future success. The private bank Lombard Odier Darier Hentsch (0412 - text only ad) try to convince the reader that "more than 200 years of banking teaches us that the best institutions emerge stronger from volatile periods". Interestingly the ad ends with an incomplete sentence: "The next 200 years". Generali assert that the " 175 year track record of looking after our clients" interests... has confirmed the group's reputation as a safe haven whatever the market conditions may be". They do so in a full page ad where the only image is the company's logo. Also, recent histories of success are alluded to in the number of references to awards. For example, both HSBC (2401) and Standard Chartered (2702) list a seemingly endless number of awards they won in 2007 (best in 32 and 42 categories respectively), to the point of making the concept of 'award' meaningless. If we consider the ads that refer to size, history, or both size and history, the pattern of 'response' to events becomes even more pronounced than in figure 2, with this type of ad clearly peaking in September and October 2008. 
- Insert Figure 3 about here -

Insurance companies, perhaps unsurprisingly, offer to manage 'risk' most prominently in our sample. For instance, Allianz suggest that their services allow their clients to "sail into an open horizon... [and] give you the confidence you need whatever your moment" (0203). ACE ads are a little more explicit with their promises, stating: "Let ACE take on the responsibility of risk... [and] free you to focus on the possibilities not the liabilities" $(2804,0606,0909)$. Images of architectural frames, cargo ships and super technology are used to create a sense of awe about ACE. The play between text and images is designed here to inspire confidence. Peace of mind is ensured through nullifying the very the notion of risk. Allianz boldly suggest later in the year: "the risks are covered" (0310 - image of three men in suits wearing hard hats). Here risk is not just accepted but defeated; it no longer has any teeth. Allianz also suggest that the sponsorship of safety cars in F1 races is a form of risk management; thus subtly equating the prevention/ mitigation of risk with the 'management' of risk. Interestingly they exude a sense of continuity by changing their ads slightly for 12 different races. One set of ads has an image of an Allianz sponsored F1 safety car on a race track, only changing the name of the circuit where the race is taking place that week: "Safety First. At Monza and on the road (1309)"; "Safety First. At Hockenheim and on the road (1907)", etc. Another set of ads goes into the specifics of the individual race whilst using the almost identical image of a F1 car and a sketch of the race track in question: "Fuji Speedway. The longest straight in Formula One (1010)"; "Monza. The challenging Parabolica (1209)", "Circuit de Monaco. The most demanding race of all (2305)".

This approach to risk is taken a step further by a series of ads (eight in total) by CME (Chicago Mercantile Exchange). For CME risk indicates potential as their clients "harvest opportunities from risk" (1709), "never let risk restrain [their] potential" (0503), and where "managing risk is an art in itself" (3004). In each case we are presented with an image of a successful businessman holding some kind of 'prop' which tries to play with the strap line of the ad. Thus, for example, we have the CEO of Bluecrest Capital Management holding a lion on a leash whilst standing in front of the UK Houses of Parliament, with the strap line: "A risk tamed is a reward captured" (2401). Yet the sentiment projected by this series becomes undermined by the rather frantic advertising (five identical full page ads published from late September onwards) where CME promises to "provide confidence in an uncertain world" and help its clients "Rise Above the Risk". It is an ad which is heavy on text (it contains a small cartoon image we referred to earlier of a man on a mountain top above the clouds) and which proclaims earnestly that "CME group protects customers and ensures financial integrity... No clearing member has defaulted and no customer has ever lost funds due to counterparty failure... At a time of unprecedented uncertainty in financial markets CME can help you rise above the risks". So by September 2008 'Risk' had become something that needed to be harvested, while at the same time 'risen above', protected against, and artfully managed... Not for the last time we reach a point of what we could call 'financial zaum'. Zaum is a word first made up by the Russian futurists in 1912 which, "if it means anything at all, means that words have no necessary, inherent meaning" (Conrad, 1998: 111); its coinage sums up the crisis of confidence suffered by language when confronting a world it can no longer describe. 


\section{The Void in Finance}

A perusal of the ads suggests that they seem to distance the advertising organizations from the dominant logic of finance capital: a focus on profit and shareholder return maximization. Merrill Lynch, for example, proudly claim they are "Creating wealth beyond money" (0801). A multitude of ads present a caring and committed image of the organization in question. UBS state, "You and Us. The world changes but our commitment doesn't." (1609) and "You and Us. The times are uncertain. The relationship isn't." (0305). These strap lines are accompanied by images of grey-haired bankers. Merrill Lynch boast of their "Unwavering commitment to our clients", and Deutsche Bank are "committed to our clients' success through all market conditions". This commitment is even expressed towards entire continents as well. In an ad with somewhat unfortunate imperialistic echoes Standard Chartered (3107) remind us that, "One bank made a commitment to Africa more than 150 years ago." This 'caring' dimension is pushed even further in a series of ads titled "Close and Strong" by Santander. Each ad features a warm embrace. Images include: a child hugging the leg of a parent (0112), a girl hugging a tree (1711), a loving couple on the beach (2111). With each ad the caption reads: "This is how we want our 80 million customers, 2.8 million shareholders, and 170,000 employees to feel about us. Like the best bank in the world." Santander clearly want to elicit a deep loving affection from all customers, shareholders and employees. These ads seem to illustrate Boltanski and Chiapello's argument (2005) that capitalism cannot function without an ideology that justifies it in terms of the 'common good'; its legitimation requires a moral appeal to this 'common good' and it will therefore appropriate emancipatory discourses of commitment and self-fulfilment (Kemple, 2007).

Financial organizations included in our sample constantly refer to their engagement with a variety of cultural or sporting events while only tangentially referring to their business operations. It is almost as if the finance industry recognizes it is void of meaning or values and therefore must make constant reference to the indirect value it brings to, or the support it provides for, the non-economic sphere. The associated images (of, for example, a cello player, a racing track, an art gallery, cultural icons, family life, a busy marketplace...) give the illusion of substance, of the ads having 'content'. Anything which can help lend an aura of solidity, permanence, and integrity to the organization (especially in times of crisis) will do, however incongruous the fit to its business may be.

We can see this in ads which make simple reference to culture like Deutsche Bank's reference to the Frieze Art Fair (0910) or the cultural references alluded to in the Vienna Stock Exchange series. Cartoon images for the latter include: a couple waltzing (0907), a rider from the Spanish riding school (0309), a man playing the violin (1806), the famous Prater Ferris wheel (1509). Mizuho ran a series of ads (eight in total) consisting of reproductions of various works by Hokusai and Hiroshige with most of the copy devoted to an art-historic analysis of the painting. The only commercial element is to be found in the strap lines: "Powerful implementation, global impact"; "Pioneering vision, innovative integration"; or "Challenging concepts, dramatic results". Allianz and Santander heavily play on their sponsorship of F1 (12 and 9 ads respectively). In an almost comically hyperbolic series of ads using images of sleeping children ('Kate Never Sleeps' (0206) and 'Dreams Never Sleep' (1205)) Citi group suggest: “Kate's world is being enhanced by those near and far. And every minute Citi is helping". Likewise Standard Chartered proclaim they are "Supporting Communities While Securing Wealth" 
(hybrid image of bank vault and Asian peasant making round net - 1711) and "Enriching Lives While Enhancing Industries" (hybrid image of human eye and camera lens 2411). Interestingly, the Credit Suisse advertising campaign has an ironic but rather revealing take on this lack of values. Their ads re-instate the image of the sensible, economically rational financial world lost within almost desperate attempts of the other financial actors to be anything but boring financial institutions: "Some think savouring life. We think return on investment." (0110, image of three people tasting wine in cellar); "Some think dream come true. We think corporate finance." (0403, image of three people talking in front of boat); "Some think standing ovation. We think outstanding performance." (2309, image of two opera singers taking in applause).

The constant need of financial actors to establish themselves as having cultural value for society is revealing in that such a positive fantasy may be concealing a traumatic lack. Perhaps they are trying to close off an alternative reality - one in which the financial industry has minimal cultural value for society, that is, where financial institutions are simply meaningless facilitators of the economy. This is not to deny the efficacy of such a move of course. These ads may thus offer a "a trace of the true" in that they point to the incapacity of capitalism to offer intrinsic libidinal investments to its subjects; to its urgent internal need to reinvent and continuously appropriate older forms of coding. They are an example of a translation process that incessantly needs to spell out the role of the financial industry in its larger social context. This is because, as both Badiou (2006) and Žižek (2008) have pointed out, capitalism cannot offer a civilization of its own, with its specific way of rendering life meaningful. Thus capitalism mobilizes alreadyexisting things whose legitimacy is guaranteed, to which it then gives a new twist by combining them with the exigency of capital accumulation (Boltanski and Chiappello, 2005).

\section{Ideology, Form and Utopia}

Finance capital requires a libidinal apparatus in order to be culturally secured, especially perhaps in times of crisis. Unlike with the abstract notions of neo-classical economics, one might thus expect to find promises and possibilities buried within the imaginaries of finance capitalism; some way of discovering 'the best in the worst'. While the first part of this section explores two examples of the way "form crystallizes modes of ideological perception" (Eagleton, 2002: 63) the second part explores the 'other spaces' organizations allude to in the face of the crisis. The ads deliver a promise of distance and shelter from the turbulence and uncertainties created by capitalism; a promise that financial markets are somehow separate and different from the financial actors constituting these markets, and that existing methods and modus operandi (which by all accounts created the crisis) hold the key to 'rising above' the crisis.

The ads published in most direct response to the meltdown tended to take the form of full-page text-only ads (e.g. ACE 1809, AIG 2609 and Citi 2611). At a first glance the image-work has broken down. AIG's ad is typical and takes the form of an open letter by the chairman and CEO. It is important to remember the temporal context. This is just over a week after the US government took a $79.9 \%$ stake in the company whilst government analysts and accountants from the world's leading investment banks could not figure out how much cash the company would require in order to collateralize its credit default swaps; over the course of a weekend estimates rose from $\$ 20 \mathrm{bn}$ to $\$ 85 \mathrm{bn}$ (Caldwell, 2008). The ad states: 
"Thank you for sticking with us. All 116,000 employees appreciate your confidence... Be assured that our insurance companies remain strong and well capitalized... Regulations ensure that the assets of our insurance companies are there to back up each policy. You are protected. Your policies are safe.

I'll be communicating with you as we mold AIG into a strong, nimble and vital organization focused on exceeding your expectations and securing your future".

No image could capture the severity of AIG's situation. Here the text, plain and 'honest', is the image. We are reminded here of Marx's insight that form is determined by the type of content it has to embody, a content which is historically determined and by no means "a mere quirk of the individual artist" (Eagleton, 2002: 21). The ad takes form of the most basic form of business communication: the office memo. It represents a plea or maybe even a practical business request from one business man (the chairman) to another (the reader/investor). The ad is serious and honest (in form if not content), reflecting a desperate time for the company.

The crisis also caused subtle shifts in the campaigns of the hardest-hit organizations. For example, Merrill Lynch published a series of ads with an identical image in January, July and October (the final image has been zoomed out slightly, but only marginally so): that of a powerful bull standing on a hill overlooking/guarding the city below. Each of the ads seemed to be published just after a low point in the share price: the first one after a break through the $\$ 20$ share floor, the second one on the day the share price fell to a record low of $\$ 13$, and the final one appeared after the Bank of America takeover and a dramatically volatile period for the share price in which it broke through the $\$ 10$ price floor. In January and July the ads retained the same form with strap lines that promise "unwavering commitment" to clients. The image takes up approximately $75 \%$ of the copy, with a few lines of text added. The image of the ad published in October only takes up $40 \%$ of the copy. The text, resembling the format of a poem, reads:

"Every economy of the world has weathered difficult times before. At Merrill Lynch, we understand that in the middle of the storm, it is hard to limit emotions.

But our faith in the global economy, its markets and its people is unwavering. For they have always found a way to come back and grow over the long term.

That's not a belief. That's history."

This ad offers a veritable cornucopia of contradictions and tensions. We note just two in passing. First, there is the rather explicit contradiction between the phrase "But our faith in the global economy" and the later statement "That's not a belief. That's history". Merrill Lynch's modest plea for an unemotional consideration of its historical facts hangs the evidence of global market recovery on history not belief, thus distancing itself from the fact that global recovery is only at best a 'belief statement'. A second contradiction exists between the poetic structure and uplifting prose of the text and the statement "It is hard to limit emotions". While attempts have been made within the content of the poem to 'limit emotions', this content sits within a historically 
emotional form, that is, a poem. In Macherey's (1966) terms such a conflict of meanings between form and content is produced by the work's relation to ideology. Here the ad's interplay of form and content fails to suture the ideological ruptures that characterized the economy in late 2008.

The sample of ads considered in its entirety also offers a vision in more general terms: a closure to the excesses of capitalism. Examples of the 'capitalist way out of the crisis' can be found in the ads where financial players argue that they can offer 'solutions' to the financial crisis whilst still living the dream of capitalism. A large group of companies emphasize their performance and success in 'turbulent times': BNY Mellon (0206), Barclays Capital (2301), Invesco Pertual (2903), Dexia (2204), Anglo Irish Bank (0805), RZB (0110), HSBC (0508)... Other players such as Deutsche bank and Fortis go further and incorporate images of the crisis (without ever mentioning the c-word of course) into their campaign. Images of uncertainty and turbulence (i.e. waves and curves) are contrasted in Deutsche Bank's case with their large solid logo rising out of the sea $(1803,2305,0407,1609,1909)$ or trivialized as in Fortis's ads which show a series of curves $(1606,2306,2808,1909)$. One example shows a cartoon man sleeping on a curve with the strap line "life is a curve. Where are you on it?" (1606). In promising certainty, solidity and simplicity (through, for example, the reference to size, risk and history described above) many of the organizations included in our sample were essentially offering a closure to the key symptoms that made finance capitalism appealing in the first place: dynamism, turbulence, exchange and wild profits.

The question remains as to whether these closures to the excesses of capitalism represent a capitalist utopia? Whilst visions of a safe, symptom-free capitalism are provided through our sample of FT ads, these ads contain no essential enabling mechanisms beyond the rather fashionable references to risk management. As such they are little more than some wishfulfillment of private fantasies from our present vantage point (Jameson, 2005). The 'other spaces' on offer do not really promise an alternative to, but rather a closure and separation from, the present.

\section{Concluding remarks}

"This raises the question as to how you destroy a charade that is not a secret but a public secret (something that is known by everyone, but not easily articulable). For it would seem that such a phenomenon has built-in protection against exposure because exposure, or at least a certain modality of exposure, is what, in fact, it thrives upon" (Taussig, 1999: 216).

We constructed our 'financial phantasmagoria' with the aim of critically engaging powerful received forms of recent historical narrative and causality, bringing to the fore the various contradictions these contained (cf. Jameson, 2007). We found that the financial institutions advertising in the FT during 2008 distanced themselves from the critical events in the global economy whilst re-confirming their centrality in that same economy. Interestingly the word 'crisis' was not adopted by a single organization, but instead certain images (e.g. waves, curves) and words (e.g. turbulent, uncertain times) were deployed with the aim of naturalizing or 
sanitizing the crisis situation. References to size and history were used within ads to make organizations seem beyond the crisis in both temporal and spatial terms. In the autumn of 2008 financial imaginaries most obviously failed what Fairclough (2006: 23) calls the 'reality test', the requirement that "the imaginaries they project for space-time cartographies are grounded in actual constructions of space and time as they are practically experienced through people's engagement in the world". Yet, even this apparent break-down in the image work still had an important performative dimension: constructing a world without any depth makes it very difficult to critically denounce that world. The organizations contained in our sample simply constructed the crisis as an outside space against which they could offer certainty and a time during which they could provide 'commitment to clients'. These various closures to the excesses of finance capitalism offer a rather 'flat' but pleasing vision of 'capitalism without its symptoms'. Financial imaginaries can thus be seen playing an important role in facilitating "the displacement and/or deferral of associated contradictions, conflicts, and crisis-tendencies elsewhere and/or into the future" (Jessop, 2008: 14).

Against this continuous deferral/displacement financial imaginaries facilitate, our paper aims to stage a creative confrontation with the public secret that the reality of finance capital is 'really made up', that there is nothing natural about financial markets continuing to pose as an integral part of our life-world, playing an essential role in enabling us to get along (again!) with our everyday lives. However, one must be weary not to treat this process of creative confrontation as a simple unveiling of a secret as "there may be nothing more dissatisfying than the exposed secret, the triumph of exposure giving way to some vague sense of being cheated" (Taussig, 1999: 157). Such a simple exposure may turn out to reinforce the very reality of finance capitalism. Evidence of finance capitalism's "built-in protection against exposure" can be found in the speed with which a new 'normality' and 'business as usual' have been constructed in the aftermath of the financial crisis, and the alarming degree of continuity which has been established with the pre-crisis situation, thus papering over the various recently exposed social and economic tensions (Panitch and Konings, 2009). In Benjamin's (2002) terms our aim has been then not to lift the veil of financial imaginaries, but develop some understanding of their operation as a veil which has made, and continues to make, certain aspects of the recent period of 'capitalism in crisis' very hard to question.

Breathe freely now! The market's getting well! Again the doldrums have been overcome. The difficult task has once again been done. And once again a plan is finely spun.

And the world resumes the way we like it run.

Brecht (1962: 187), fragment from Saint Joan of the Stockyards 
Figure 1: Historical profitability data USA
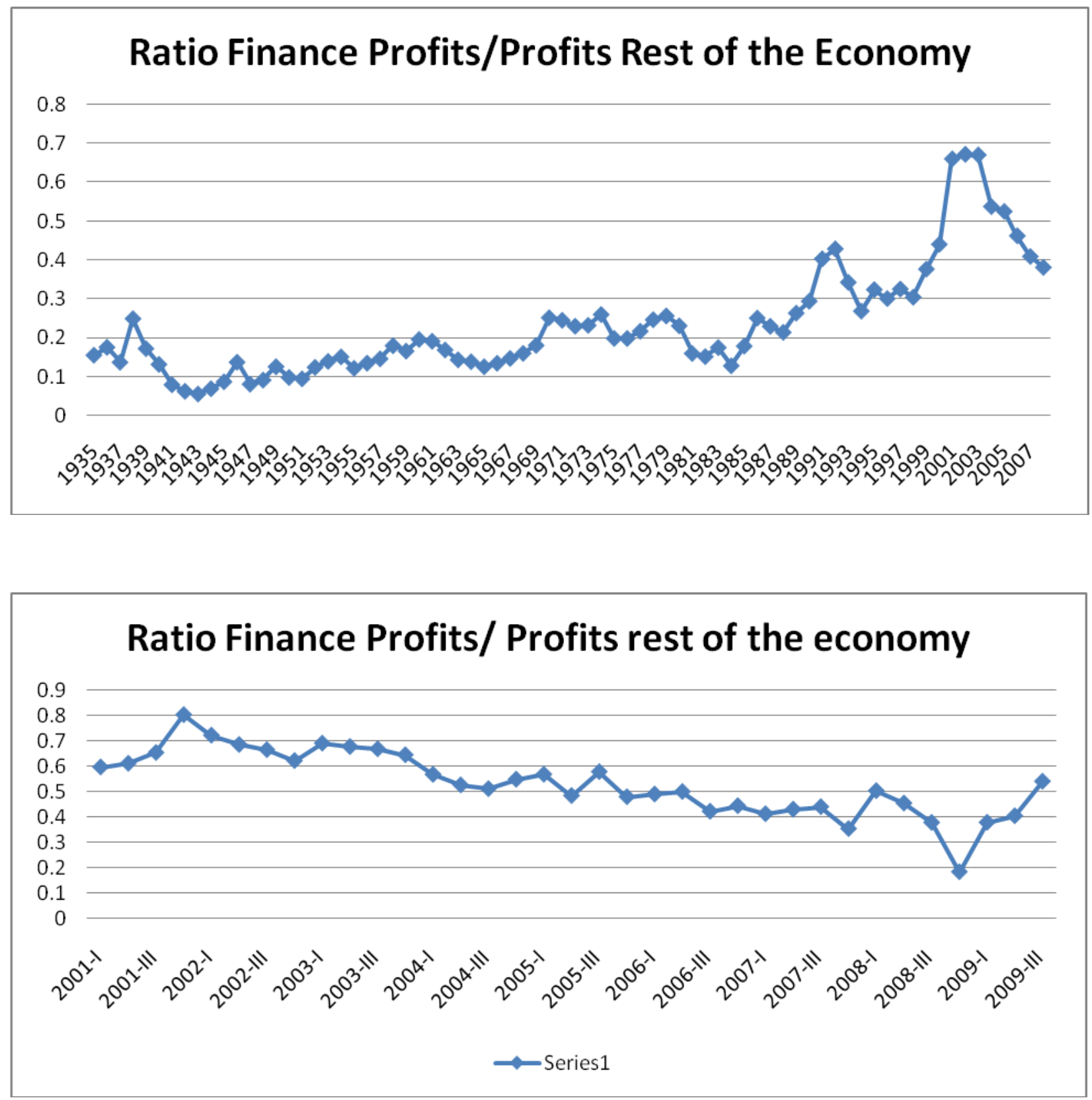
Table 1: Share price movements of selected Financial Institutions (source Financial Times)

\begin{tabular}{|c|c|c|c|c|}
\hline Share Price & $01->042008$ & $05->082008$ & $09->122008$ & $\begin{array}{c}\text { Number of ads } \\
\text { published in } 2008\end{array}$ \\
\hline ING & $1 \%$ & $-18 \%$ & $-65 \%$ & 5 \\
\hline HSBC & $4 \%$ & $-11 \%$ & $-39 \%$ & 20 \\
\hline Fortis & $-5 \%$ & $-43 \%$ & $-91 \%$ & 4 \\
\hline Deutsche Bank & $19 \%$ & $-22 \%$ & $-54 \%$ & 15 \\
\hline Credit Suisse & $-8 \%$ & $-15 \%$ & $-40 \%$ & 12 \\
\hline Allianz & $-9 \%$ & $-15 \%$ & $-34 \%$ & 18 \\
\hline AIG & $-17 \%$ & $-53 \%$ & $-93 \%$ & 1 \\
\hline Mizuho & $0 \%$ & $-10 \%$ & $-44 \%$ & 8 \\
\hline Santander & $3 \%$ & $-22 \%$ & $-44 \%$ & 14 \\
\hline Standard Chartered & $0 \%$ & $-19 \%$ & $-41 \%$ & 10 \\
\hline UBS & $-20 \%$ & $-38 \%$ & $-34 \%$ & 8 \\
\hline $\begin{array}{l}\text { Bank New York } \\
\text { Mellon }\end{array}$ & $-4 \%$ & $-23 \%$ & $-19 \%$ & 4 \\
\hline $\begin{array}{l}\text { Bank of America } \\
\text { (+ Merrill Lynch) }\end{array}$ & $0 \%$ & $-18 \%$ & $-56 \%$ & $1(+6)$ \\
\hline AVERAGES & $-3 \%$ & $-23 \%$ & $-50 \%$ & \\
\hline
\end{tabular}


Figure 2: Advertisements published for first time during month

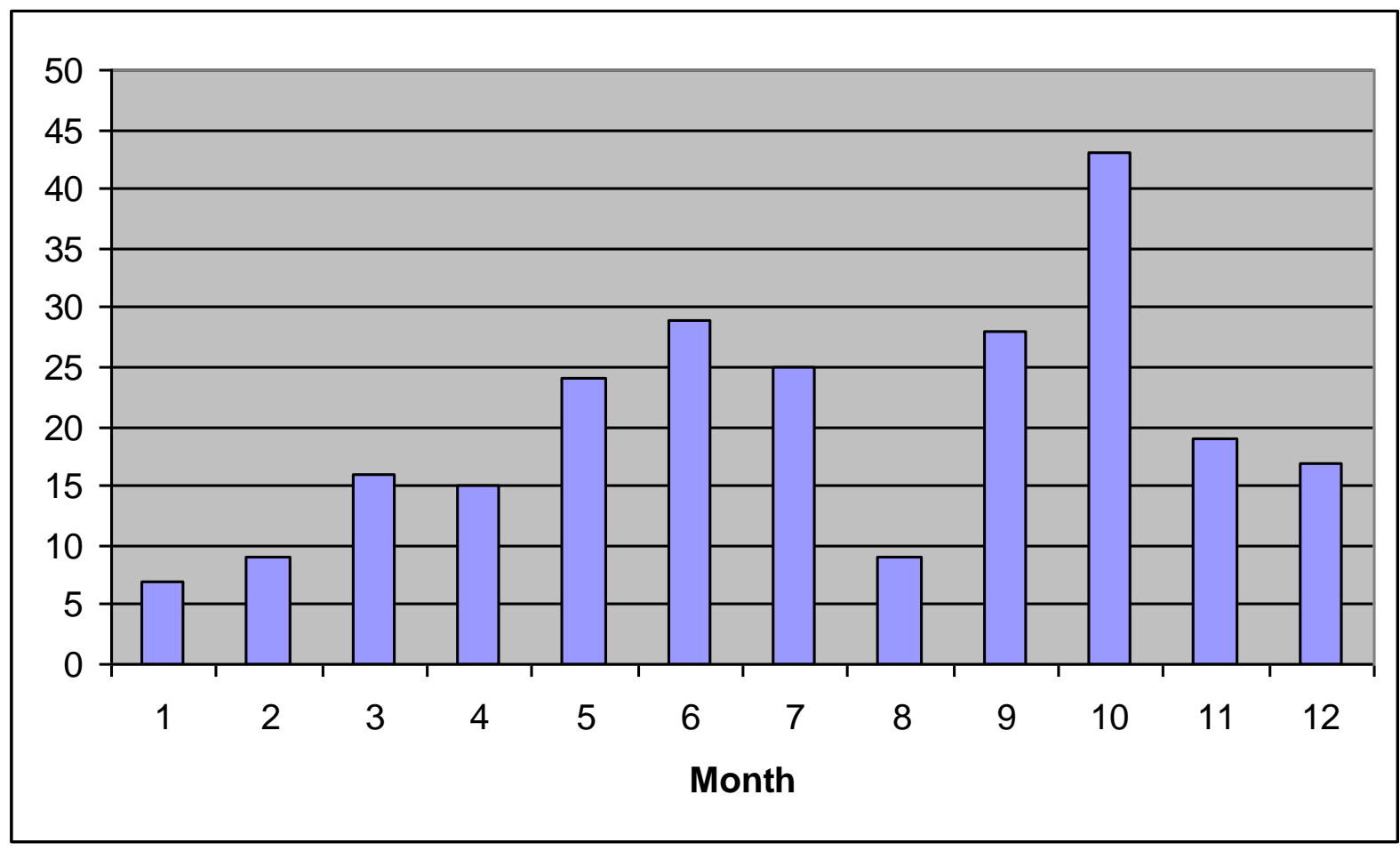

Figure 3: Advertisements mentioning size, history or size $\&$ history

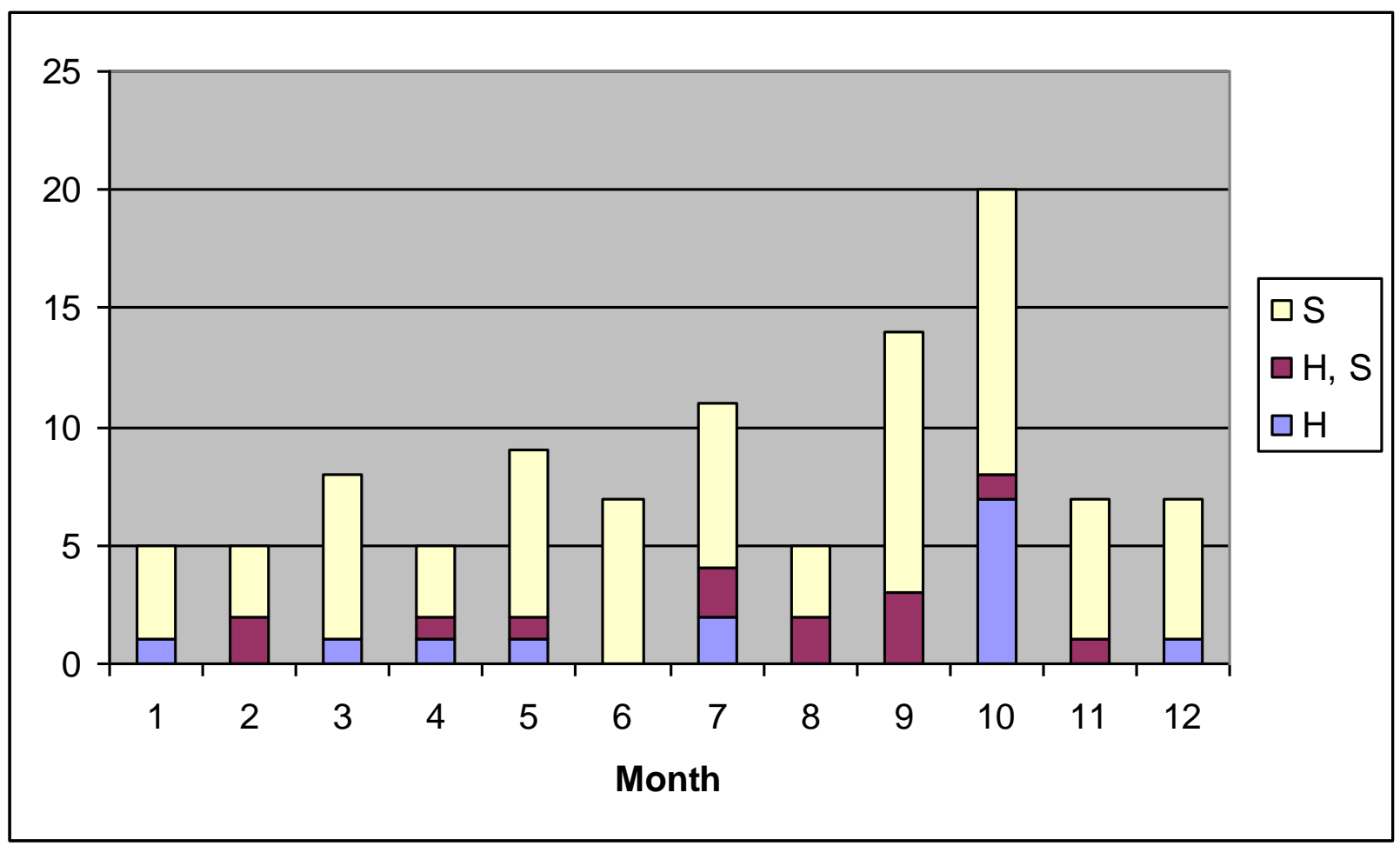




\section{References}

Amin, A., \& Thrift, N. 2004. Introduction. In A. Amin, \& N. Thrift (Eds.), Cultural Economy Reader: X-Xxx. Oxford: Blackwell.

Badiou, A. 2006. Polemics (S. Corcoran, Trans.). London: Verso.

Barthes, R. 2000. Myth Today. In S. Sontag (Ed.), A Roland Barthes Reader: 93-149. London: Vintage.

Benjamin, W. 2002. Selected Writings, Volume 1: 1913-1926. Harvard: Harvard University Press.

Blackburn, R. 2006. Finance and the Fourth Dimension. New Left Review, 39(39-70).

Blackburn, R. 2008. The Subprime Crisis. New Left Review, 50(2): 63-106.

Boltanski, L., \& Chiapello, È. 2005. The New Spirit of Capitalism (G. Elliott, Trans.). London: Verso.

Brecht, B. 1962. Plays Volume II. London: Methuen.

Buck-Morss, S. 1995. Envisioning Capital: Political Economy on Display. Critical Inquiry, 21(2): 434-467.

Buck-Morss, S. 2007. Visual Empire. Diacritics, 37(2-3): 171-198.

Busfield, S. 2009. Financial Times dips as qualities score sales boost, Guardian, February 6th ed. Manchester.

Caldwell, C. 2008. There is no free lunch and no free economy either, Financial Times, September 20th ed. London.

Conrad, P. 1998. Modern Times, Modern Places: Life \& Art in the 20th Century. London: Thames \& Hudson.

Culler, J. 1983. Barthes. London: Fontana Paperbacks.

Davis, A. 2005. Media Effects and the Active Elite Audience: A Study of Communications in the London Stock Exchange. European Journal of Communication, 20(3): 303-326.

De Cock, C. 2008. Adventures in Financeland. Organization, 15(6): 946-956.

Eagleton, T. 2002. Marxism and Literary Criticism. New York: Routledge

Evans, J., \& Habbard, P. 2008. From Shareholder Value to Private Equity - The Changing Face of Financialisation of the Economy. Transfer, 14(1): 63-76.

Fairclough, N. 2006. Language and Globalization. London: Routledge.

Freeland, C. 2008. Leader's tricky challenge of saving US from hell, Financial Times, December 19 ed. London.

Froud, J., Leaver, A., \& Williams, K. 2007. New Actors in a Financialised Economy and the Remaking of Capitalism. New Political Economy, 12(3): 339-347.

Froud, J., Johal, S., Leaver, A., \& Williams, K. 2008. Ownership Matters: Private Equity and the Political Division of Ownership. CRESC Working Paper Series, 61.

Glyn, A. 2006. Capitalism Unleashed: Finance Globalization and Welfare. Oxford: Oxford University Press.

Gowan, P. 2009. Crisis in the Heartland: Consequences of the New Wall Street System. New Left Review, 55(1): 5-29.

Grant, J. 2009. LSE to ring changes to rival NYSE bell, Financial Times, 28 October ed. London.

Hopwood, A. G. 2009. The economic crisis and accounting: Implications for the research community Accounting, Organizations and Society, 34: 797-802.

Jameson, F. 1997. Culture and Finance Capital. Critical Inquiry, 24(1): 246-265. 
Jameson, F. 1998. Brecht and Method. London: Verso.

Jameson, F. 2000. Globalization and Political Strategy. New Left Review, 4(4): 49-68.

Jameson, F. 2005. Archaeologies of the future: The desire called utopia and other science fictions. London: Verso.

Jameson, F. 2007. Jameson on Jameson: Conversations on Cultural Marxism. Durham (NC): Duke University.

Jessop, B. 2004. Critical Semiotic Analysis and Cultural Political Economy. Critical Discourse Studies, 1(2): 159-174.

Jessop, B. 2008. A Cultural Political Economy of Competitiveness and its Implications for Higher Education. In B. Jessop, N. Fairclough, \& R. Wodak (Eds.), Education and the Knowledge-Based Economy in Europe: 1-26. Rotterdam: Sense Publishers.

Kemple, T. 2007. Spirits of Capitalism. Theory, Culture \& Society, 24(3): 147-159.

Lash, S. 2007. Capitalism and Metaphysics. Theory, Culture \& Society, 24(5): 1-26.

Macherey, P. 1966. Pour une théorie de la production litteraire. Paris: Maspero.

Montgomerie, J., \& Williams, K. 2009. Financialised Capitalism: After the Crisis and Beyond

Neoliberalism. Competition \& Change, 13(2): 99-107.

Morone, J. 2007. El Casino Macabre. London Review of Books, 29(12): 28-30.

Panitch, L., \& Konings, M. 2009. Myths of Neoliberal Regulation. New Left Review, 57(3): 6783.

Pryke, M., \& du Gay, P. 2007. Take an issue: Cultural economy and finance. Economy and Society, 36(3): 339-354.

Rancière, J. 2004. The Politics of Aesthetics: The Distribution of the Sensible (G. Rockhill, Trans.). London: Continuum.

Rancière, J. 2007. The Future of the Image (G. Elliott, Trans.). London: Verso.

Taussig, M. 1999. Defacement: Public secrecy and the labor of the negative. Stanford: Stanford University Press.

Thompson, G. 2009. What's in the frame? How the financial crisis is being packaged for public consumption. Economy and Society, 38(3): 520-524.

Thrift, N. 2008. Non-Representational Theory: Space i politics i affect. London: Routledge.

Watt, A., \& Galgóczi, B. 2009. Financial capitalism and private equity - a new regime? Transfer, 15(2): 189-208.

Žižek, S. 2008. Violence: Six Sideways Reflections. London: Profile Books.

Žižek, S. 2009. To Each According to His Greed. Harper's Magazine(October): 15-18. 